\title{
Moral and political conceptions of human rights: rethinking the distinction
}

\section{Anita Sophia Horn}

To cite this article: Anita Sophia Horn (2016) Moral and political conceptions of human rights: rethinking the distinction, The International Journal of Human Rights, 20:6, 724-743, DOI: 10.1080/13642987.2016.1147433

To link to this article: https://doi.org/10.1080/13642987.2016.1147433

册Published online: 22 Feb 2016.

Submit your article to this journal $\pi$

Џlll Article views: 1352

Q View related articles $\smile$

View Crossmark data $[\pi$

Citing articles: 1 View citing articles ¿ 


\title{
Moral and political conceptions of human rights: rethinking the distinction
}

\author{
Anita Sophia Horn* \\ Department of Philosophy, University of Zurich, Zurich, Switzerland
}

\begin{abstract}
In one important strand of the philosophical debate, human rights are seen as a practical benchmark to evaluate and orient matters of national politics, international relations and global governance. The article investigates the possible benefits and problems of this approach. Problematising the well-established distinction between moral and political human rights in philosophical human rights debate, the author follows Paolo Gilabert's attempt to alternatively discuss human rights under the perspective of rights having both an abstract and a specific dimension. Discussing the (self-) understanding of the contemporary human being as representing the subject of human rights, Axel Honneth's recognition theory is applied to concretise Gilabert's humanist claim to do justice to the 'essentially social' nature of the human being. While holding on to the traditional idea that human rights are in first instance to be understood as individual rights human beings have in virtue of being human, the important international political function of human rights is accounted for by introducing the term cosmopolitan rights.
\end{abstract}

Keywords: human rights; political and moral conceptions; recognition theory; Paolo Gilabert; Axel Honneth

\section{Introduction}

One of the key questions in current philosophical human rights debates concerns the compatibility of moral and political rationales as a basis for a consistent justification of human rights. Effectively, the development of human rights since the end of World War II has created a 'universally accepted value system'. The claim that human rights have become "the dominant doctrine for evaluating the moral status of the contemporary geo-political order' ${ }^{2}$ is deemed to be a safe belief. Yet, despite the human rights boom in practice, scholarship on human rights is drifting apart to the extent that the label 'human rights' appears to be the only common denominator. James Griffin states in his article 'Human Rights: Questions of Aim an Approach':

What are we philosophers, political theorists, and jurisprudents trying to do? One might think that the answer is obvious: we are trying to understand better what human rights are. But the answer is most unclear. 'Human rights' as used in ethics? Or in law? Or in political life? [ ... ] All of these different aims require different approaches. $[\ldots]^{3}$

*Email: anita.horn@uzh.ch 
A brief look at the relevant literature in philosophy shows a remarkable heterogeneity of rationales and normative, empirical and political arguments for defining, justifying and applying the concept of human rights. Human rights are, of course, a topic in political science, law and philosophy, but particularly in view of the latter there is a divide between moral and political philosophy. Griffin insists that the lack of a common concept of human rights leads both to differences regarding the nature of the problem and to its solution. ${ }^{4}$ Tellingly, lists of human rights provided by philosophical scholars diverge significantly depending on whether they take human capabilities, needs, interests, (collective) self-determination or political feasibility as theoretical anchors for their accounts. Like many other scholars trying to order the conceptions, Fabienne Peter suggests that human rights should be categorised according to the Rawlsian distinction between 'traditional' and 'political' conceptions:

According to the traditional conception, human rights are moral rights that people have qua salient features of their humanity. These features may relate to fundamental needs or interests (e.g., Miller 2012) or basic aspects of human agency (e.g., Griffin 2008). According to the political conception, by contrast, human rights are a set of special rights that have their origins in salient features of contemporary human rights practice (e.g., Rawls 1999; Beitz 2009). ${ }^{5}$

According to this line of reasoning, political conceptions of human rights typically grasp them as a given practice of public reasoning in a form of bottom-up approach. ${ }^{6}$ Representatively, Charles Beitz states that human rights are a public enterprise, and that 'those who would interpret its principles must hold themselves accountable to its public aims and character'. ${ }^{7}$ Human rights name 'not so much an abstract normative idea as an emergent political practice'. ${ }^{8}$ The emphasis of the human rights concept's paramount practical function is understood to account for doctrinal and political complications shaping the actual debate. The functional role of human rights in international discourse and practice is taken as the basic constraint of political conceptions of human rights:

A practical conception takes the doctrine and practice of human rights as we find them in international political life as the source materials for constructing a conception of human rights. [...] There is no assumption of a prior or independent layer of fundamental rights whose nature and content can be discovered independently of a consideration of the place of human rights in the international realm and its normative discourse and then used to interpret and criticize international doctrine. ${ }^{9}$

Defining human rights as a mere 'set of special rights' originating from practice, does not mean that these rights must lack moral content. However, the focus of justification and orientation clearly shifts away from genuine moral theoretical and anthropological reflections to deliberations about actual political and juridical practices and practicalities. By contrast, moral conceptions (i.e. 'traditional' conceptions in Peter's vocabulary) interpret human rights primarily as expressions of a moral idea. ${ }^{10}$ In this latter view, human rights are understood as individual, extra-positive, moral rights that aim at protecting negative liberties and at guaranteeing positive liberties. They serve as an ideal benchmark to determine legal rights and political standards in a sort of top-down approach.

This article is structured in three parts. In Part I, I sketch two historical interpretations, which have led to the contemporary primacy of the political conception of human rights. I then challenge the very distinction between moral and political conceptions by showing that the latter fail to be independent of substantive moral assumptions. Political conceptions are, 
at least partly, moral conceptions, too. In Part II, I refocus the debate by elaborating a moral conception that takes central (political) criticisms into account. The proposed moral conception focuses on the intersubjective, social dimension of human rights. I first elaborate Paolo Gilabert's claim of an explicit conceptual distinction between abstract (moral) human rights and specific (practical) human rights. His conception of the humanist selfunderstanding that has to ground human rights reasoning is extended by Axel Honneth's recognition theory. Finally, in Part III, the demand for political feasibility of human rights in the global political context leads to the distinction between (abstract and specific) human rights and (abstract and specific) cosmopolitan rights. The intersection - it shall be argued - of the local, individual and intersubjective dimension of human rights with their global political dimension should take centre stage within the debate.

\section{From moral to political conceptions: two historical tracks leading towards a practical interpretation of human rights}

The history of human rights is marked by two distinct historical interpretations, each documenting the relative rise of political conceptions to the disadvantage of moral conceptions of human rights. ${ }^{11} \mathrm{~A}$ first trajectory emanates from human rights as historically linked to Enlightenment philosophers (e.g. Locke and Rousseau) under the label 'natural rights'. ${ }^{12}$ Understanding human rights as natural rights implies 'that moral agents have these rights because of their very nature as humans (or moral agents)'. ${ }^{13}$ This idea of human rights drove the English, American and French revolutions in the seventeenth and eighteenth centuries; the revolutions 'were proclaimed and conducted in its name, as was the struggle against slavery'. ${ }^{14}$ The human was understood as a rational being, capable of self-development and the ongoing realisation of a better, progressive society.

In the course of secularisation, however, the idea of natural rights rooted in Christianity and the absoluteness of the values system became questioned. Whereas the general idea of universal human rights is unquestioned in academic discourse, the criticism against particular facets of universalism is widespread under the headings of 'cultural-relativism' on the one hand, and 'formal properties' such as fundamentality, subjectivism, generality, egality, absoluteness and indivisibility on the other hand. The cultural-relativist objections can be summarised under the headings 'decontextualism', 'euro-centrism', 'anti-pluralism', 'individualism' and 'imperialism'. ${ }^{15}$ The objections of decontextualism and euro-centrism are both directed to the fact that self-understanding, customs and correlating rights-systems diverge according to different cultures. The objection of decontextualism argues that equality and justice need to be interpreted respectively to the concrete life-conditions of individuals and communities. The euro-centrism objection claims that the historical genesis of human rights is closely intertwined with the Western thought tradition. The one-to-one adaption to non-Western cultures is put into question. Derived from these reservations, the anti-pluralism objection warns from an authoritative dominance of the continental conception of the good life that displaces intercultural variety. The prominent scepticism against paternalistic decision-making in human rights regimes is at least partly based in these kinds of objections. The value of personal autonomy, a designed paramount basic value of human life in the Western context that frames the moral philosophical thinking about human rights, is less crucial according to other cultural self-understandings. The criticism against paternalism also applies at the international level, for instance when Universal Declaration of Human Rights (UNDH)-backed humanitarian interventions are deemed paternalistic because they constrain the liberty of the affected people in their very attempt to extend it. $^{16}$ 
Contrary to the anti-pluralism objection, the individualism objection claims that human rights have to be understood as individual rights. Such individual rights are rights that every person has against any cultural community. Finally, the objection of imperialism is directed against the Great Powers' prerogative of interpretation. If human rights politics is used as a camouflage to enforce capitalist globalisation, it becomes an unreliable normative standpoint. ${ }^{17}$ Such doubts about the universal validity of human rights destabilise the normative force and moral persuasiveness. Therefore, the legitimacy of human rights that are constructed under a condition of imagined political consent rather then derived from a particular moral self-understanding seems easier to stand by in political philosophical argumentation.

A second trajectory leading to the contemporary credibility loss of substantial moral conceptions of human rights turns on a specific kind of anthropology that incorporates a primacy of reason and was undermined by the traumatic experiences of World War II. These experiences belied the idealistic idea of a dialectical development of reason-driven mankind; as Isaiah Berlin encapsulates, 'reason is the thinnest of walls against the raging seas of violent emotion: on so insecure a basis no permanent structure can ever be erected'. ${ }^{18}$ According to Jack Donnelly, it was only after World War II that human rights became a true subject of international relations as an institutionalised part of international politics. ${ }^{19}$ This is also the view of Christoph Menke and Arnd Pollmann who hold that the 'veraciously imperative' political meaning of the idea of human rights arose from the experience of the political and moral catastrophe of totalitarianism. ${ }^{20}$ They see the international human rights regimes established by the UDHR of 1948 and its contractual, liberal-democratic transformation in international law, as a direct reaction to prevent similar humanitarian disasters in the future. ${ }^{21}$ The human rights doctrine is seen as the result of an ongoing normative discourse of global political life. ${ }^{22}$ Understanding the development and practice of such practical human rights is seen as a central task helping to optimise human rights as tools that 'provide reasons for the world community or its agents to act in ways aimed at reducing infringements or contributing to the satisfaction of the rights in societies where they are insecure'. ${ }^{23}$ According to Beitz, a human rights doctrine should be constructed 'so that appeals to human rights, under conditions that will need to be specified, can provide reasons for the world community or its agents to act in ways aimed at reducing infringements or contributing to the satisfaction of the rights in societies where they are insecure'. ${ }^{24}$ Given this international political focus, the narrative of human rights as preinstitutional claims 'that individuals have against all other individuals in virtue of interests characteristic of their common humanity ${ }^{25}$ takes a backseat. However, it is exactly this humanist perspective that grounds the moral philosophical and anthropological attempts to justify human rights.

\section{The vague boundaries of political conceptions of human rights}

As Beitz states, 'because a practical conception prescinds from taking any philosophical view about the nature or basis of human rights, it can distinguish between the problem of conceptualizing human rights and that of understanding their authority'. ${ }^{26}$ Political conceptions indeed carry the advantage of theoretical parsimony, enabling practitioners to focus on mechanisms of implementation and the establishment of human rights 'authority'. One can reasonably argue that victims of torture pleading for justice do not attach much importance to theoretical background dispute. They want to know which rights are suable, to whichever international actors they can trust and whether these actors have the power of sanctions to guarantee protection and shelter. The UDHR and supplementary 
conventions serve as widely recognised manubrium to impose human rights standards upon sovereign states. They set standards and aspirations for domestic politics, international political debate, and for international treaties and global organisations. ${ }^{27}$

Why should we then blur these evident practical, legitimising features by finger pointing to the obscurity of the moral justification and conceptualisation of human rights? A closer look at politics makes clear that Beitz's claim of a successful distinction between the problem of 'conceptualizing human rights' and the problem of 'understanding their authority' based on separating political from moral philosophical views must be challenged. It is remarkable that many authors who advocate political conceptions borrow heavily from moral philosophical reasoning. Joshua Cohen for example, while working towards a political conception of human rights, introduces a minimal substantive content whose primary function is to clarify and guarantee just principles of membership in a political community. He thus evinces that political conceptions are not free from substantive moral claims. Such claims loom large in political conceptions even if they are often directed to the macro-political rather than to the individual level, e.g. by advocating principles of collective selfdetermination or of national sovereignty. Joseph Raz unites the forces of moral and political reasoning while arguing that human rights can be understood as 'synchronically universal', ${ }^{28}$ that is as rights that all contemporary living humans have.

The more plausible claim is that human rights are synchronically universal, meaning that all people alive today have them. Something like that seems to be assumed in contemporary human rights practice. This is of crucial importance, as it expresses the view that human life is valuable unconditionally, a view we tend - I hope - to take for granted, but which is not always observed in practice. So one crucial contribution of individual rights to the emerging world order is in underpinning its commitment to the value of human life. ${ }^{29}$

The reference to the 'commitment to the value of human life' showcases how moral claims are used to conceptualise and justify political human rights conceptions. At the same time, Raz inserts a disclaimer when pointing out that this view, namely that 'human life is valuable unconditionally', is only hoped for but not yet established to be correct. At any rate, the moral claim of universal validity of human rights and the emphasis on conventional, discursive political agreements generate a tension which cannot be circumvented by simply ignoring it. The legitimising uses of the vocabulary of ultimate values like dignity, equality, freedom, autonomy or liberty are widespread in practical discourse. ${ }^{30}$ Were these values to express simply the result of a global political discourse (and not also amount to substantive moral normative claims), one might wonder whether they would not be perceived as empty word shells at the service of yet another purpose, most relevantly, the (increasing) politicisation of human rights practice in light of power relations and strategic interests. Especially worthy of attention is the presumption of (successful) public reasoning as a way of integrating moral reasoning into political conceptions (by Beitz, ${ }^{31}$ Rawls $^{32}$ ). Can the presumption of public reason be justified without reverting to anthropological foundations of reason or to guiding moral principles? Even though the borrowings of political conceptions from moral reasoning are not always made transparent, these borrowings seem to have an indispensable legitimising impact. Lately even Beitz re-evaluates the idea of 'human dignity' as an element in the justification of human rights, motivated by insight into 'the inescapability of reference to the idea in human rights' and 'a more general interest in the political theory of the subject'. ${ }^{33}$ Therefore, despite the contemporary pragmatic advantages of political conceptions, the crucial question remains whether this factual normative force of human rights can be justified by 
conventional, discursive political agreements that have been worked out during the last decades. Referring to experiences of striking injustice as a motivation of international human rights commitments leads back to the questions: what kinds of harm and deficiency of humans must induce aid commitments? Which criteria demarcate rights to be human rights? Only based on the dispute about the content of human rights can the characteristic of human rights as 'salient features of contemporary human rights practice" ${ }^{34}$ then become determined. On the one hand, the unavoidability of reference to the normative content of human rights shows that the shift to political conceptions has surmounted the theoretical difficulties at first appearance only. On the other hand, this interweaving claims for reconciliation of moral and political conceptions. The problem is not that political conceptions have their implicit moral assumptions but that they underestimate their deploying power.

\section{The importance of a moral philosophical grounding of human rights}

Despite the mainstream in political theory inclining towards political conceptions to justify human rights, supplemented with minimal borrowings from moral theory, there are several reasons to keep moral theory justifications prominently in the running (and therefore not underdetermined). Concerning the justification of human rights, the abandonment of a genuine moral philosophical theory in favour of a justification that originates from practice and the idea of a reasonable public consent is controversial in at least two regards. The first concerns the assumption that the values on which the declaration stands are self-evidently given. The second concerns the corrective, referential and symbolic function that a moral philosophical rationale can provide in practical reasoning about political and legal human rights implementation.

First, along with the reinforced emphasis of legitimising political, juridical aspects of human rights, a de-emphasis on the theoretical justification of human rights promotes the widespread talk of 'self-evidence' of human rights in practice. The normative core values incorporated in the declaration, such as human dignity, freedom, equality and democracy, ${ }^{35}$ seem self-evident in the first moment, but their meaning and extent are controversial - if they are not just used as rhetorical place holders. Mark Mazower, for instance, writes that contemporary political theorists have made sure that these values and ideas 'are disembodied and plucked from historical context' ${ }^{36}$ His diagnosis refers to the displacement of extra-positive entities like 'God' or 'nature' and how these formerly legitimised the international law system and its universal validity claims. The lack of concern for and discussion of metaphysical foundations risks losing sight of the justification that motivated the introduction of human rights. Whereas it seems impossible to return to metaphysical foundations, it is necessary to insist on awareness and transparency of the particular moral self-understanding guiding the conceptualisation and interpretation of values and ideals of the declaration in the contemporary context. Such a normative groundwork must of course not be a dogmatic moral theory but a reliable starting point for ongoing reflection and widespread individual and collective identification.

Second, the shift from moral to political justifications of human rights can be seen as problematic with regard to the enforcement of human rights. Complications arise partly due to the well-established twofold understanding of human rights as moral claims and as legal rights:

Human rights are best thought of, therefore, as being both moral and legal rights. The legitimacy claims of human rights are tied to their status as moral rights. The practical efficacy of human rights is, however, largely dependent upon their developing into legal rights. ${ }^{37}$ 
The transmission from the moral to the legal rights sphere is complicated by the limits of political reality. It is only reasonable to formulate a legal right if its enforcement can be guaranteed. Whereas moral rights develop fundamental ideal conditions of a good human life, the legal form of human rights is meant to represent claims that are effectively made in contemporary political reality. Therefore, if the set of moral human rights is required to be convergent with the set of practical, legal human rights, it stays underdetermined and limited to the political conditions of the here and now. One practical problem caused by an underdetermined moral status of human rights is an increasing pressure on lawyers and experts in international law to offer exegesis of human rights. They are factually obliged to cover not only the legal expertise, but also to justify their instructions and principles from more general theoretical standpoints. Since universal human rights became a firm component of international law in the mid-twentieth century, the international jurisdiction of international law necessarily contains a supranational responsibility and accountability. ${ }^{38}$ Supranational guarantees incurred by the international community require strong elements of universality and non-negotiability of human rights doctrine. Yet, any non-negotiable doctrine contradicts the claim for bottom-up legitimation by national democracies. On the one hand, human rights lawyers and experts in international law have to insist on strong arguments of universality to uphold common human rights standards for all countries. On the other hand, they are, within the European Union, confronted with appeals to bargain about exceptions and adoptions for singular member countries. Emphasising the importance of the human rights system to deal with economic and political trials of strength, Mads Andenas ${ }^{39}$ names Greece's defiance of the most basic human rights in dealing with refugees during the Eurozone crisis since late 2009 as an alerting example to insist that scholars have to strengthen elements of universality and non-negotiability of the human rights doctrine. If human rights are mainly conceptualised and justified as 'emerging from the political practice', they are likely to become relativised by power political decisions. The reference to an independent normative basis that is legitimised through its humanistic moral arguments is therefore of practical and symbolic value. The human rights doctrine can only maintain its status as a universally accepted value system if it draws its legitimation from the moral, humanist obligation towards the human being.

However, this position arguing for a strong normative universalism leads also to fundamental concerns. Responding to Andenas, for example, Thomas Gammeltoft-Hansen points out his concern of a 'rising human rights nationalism' as it becomes expressed for example in the report of a British think tank. ${ }^{40}$ According to Gammeltoft-Hansen, the therein-uttered concern is a reaction to institutional overtaking of the human rights interpretation in the form of international 'top down law'. Instead of re-strengthening a natural law-like bulwark of universal values, he recommends exploring the understanding of natural differences.

The previous discussion shows that both moral and political conceptions of human rights seem incomplete. Authors advocating moral conceptions regret the renunciation of distinct substantive moral values that would allow operating from a constant rational standpoint and that would help avoiding relativism by providing globally reliable judgements. Authors advocating political conceptions like to keep the distinctive values of human rights preferably open to meet the criticisms of paternalism and relativism, to maintain a wider radius of operation in international politics. While moral conceptions have to reject the accusation of undue bias in their normative assumptions, political conceptions run the risk of ending up as a pawn in the hands of the powerful. Is there a practicable third way that would avoid the biased universalism of moral conceptions and balance the danger of political conceptions falling into the hands of expert technocrats and the 
powerful? Is it possible to discover a basic value concept that can serve as a structuring, motivational point of orientation?

Definitively, any sensible middle course has to face and incorporate the tension between the moral and the political function of human rights. ${ }^{41}$ My proposal is that moral and political conceptions of human rights should not be pitted against one another; the question is not whether a moral core of human rights conceptions is needed but how thick and substantive it must be, if the conception (a) seeks to be convincing from a moral philosophical standpoint, and (b) feasible and practical from a juridical and political standpoint. The inevitable tension between theoretical claims and political realisation that has to be balanced in human rights debates is directly faced, but without pretending mutual exclusion of the rationales.

\section{Refocusing the debate: the need of a shared moral standpoint to determine human rights}

Taking Gammeltoft-Hansen's above-mentioned appeal against diversity reduction through absolutist natural rights reasoning seriously, I will yet argue for the revaluation of a sphere of moral philosophical thinking about human rights, maintaining its corrective function in practice due to its original conceptual independence from considerations about international politics. In a similar vein, the article 'Humanist and Political Perspectives on Human Rights' (2011) by Pablo Gilabert suggests that the political and the moral considerations should work in tandem. I will take his account as a starting point for my own deliberations. To be clear, the natural rights idea is not incorporated as a metaphysically grounded one but rather as a conceptual framework in the way John Tasioulas phrases it:

Considered as moral standards, my claim is that human rights are best understood as continuous with what were once known as 'natural rights.' This continuity is not merely historical, but conceptual: it is not simply that the tradition of natural rights thought is part of the historical lead-up to contemporary human rights discourse, but that the ethical idea at the core of the latter is essentially that of a natural right. ${ }^{42}$

The talk about natural rights only represents the particular human (individual) rights understanding that sees their normative justification as dependent from intrinsic human needs, interests, capabilities, vulnerabilities, and so on. The 'ethical idea at the core' maintains that human rights are rights any human being has in virtue of being human. Now, how can a human standpoint of ethically determining human rights be imagined? In Gilabert's words, 'a more plausible, charitable construal of humanism' ${ }^{43}$ is necessary. In the next section, I introduce his account as a valuable starting point for my own proposal and critique.

\section{Finding a moral standpoint to derive abstract and specific human rights}

In a nutshell, Gilabert justifies his own attempt to reconcile humanist with political human rights understandings by pointing out, first, that the former already represent a substantial part of the declaration's wording. The Preamble and also the first Articles repeatedly refer to human inherent dignity, a shared self-understanding of humans as free, equal in dignity and rights. Human beings are understood as agents with reason and conscience, having the duty to act in a spirit of brotherhood. Second, he argues that global public reasoning regarding the meaning, content and justification of human rights can profit from humanist 
considerations. ${ }^{44}$ Stemming from the fact that human rights can be formulated at 'different levels of abstraction', Gilabert provides a particular distinction between a set of specific rights and a set of abstract rights ${ }^{45}$ :

We can, on the one hand, formulate a set of specific rights identifying claims that people in the contemporary world have against their own government and fellow citizens and against international organizations, foreign governments and foreign citizens. The rights of the Declaration largely operate at this level. We can, on the other hand, formulate a set of abstract rights concerned with extremely important interests shared by all (or most) human beings, whose protection involves responsibilities for anyone who can affect their satisfaction. ${ }^{46}$

According to Gilabert, specific rights 'correlate' with the given options within the contemporary international institutional framework and therefore account for political realitybased human rights implementation. This dimension therefore meets the legitimacy conditions claimed by political human rights conceptions. The set of abstract human rights 'that are held by everyone against everyone else in virtue of their common humanity, not their membership in any specific institutional structure' 47 are based on a humanist selfunderstanding. Whereas they cannot be implemented as legal rights, they function as normative guidelines in selecting specific human rights. ${ }^{48}$ Instead of sticking to the distinction between moral and political rationales, I adopt Gilabert's specification in borrowing the distinction between abstract and specific human rights to emphasise the complementarity of both rationales.

Demarcating his argumentation from a classical natural rights position and its atomistic understanding of the individual and its rights, Gilabert emphasises the understanding of human beings as 'essentially social' beings. ${ }^{49}$ The derivation of abstract rights thus requires a comprehensive social understanding of the human being. The emphasis on aspects of social life is chosen to draw a 'more plausible, charitable construal of humanism', including the capacity to reason prudentially and morally about what is good and right, about morality and physical and psychological vulnerability, the use of language and the relative capacity to modify the environment through intentional action. Further anthropological assumptions on which the derivation of abstract rights is based include the assumptions that 'humans face relative material scarcity, display tendencies to social conflict of interest and occasionally aggressive and non-cooperative dispositions, as well as benign tendencies to cooperation, respect, concern, and sympathy'. ${ }^{50}$ With regard to the human rights justification, Gilabert advocates a deliberative reflective equilibrium approach in which humanist (moral) considerations 'provide a substantive layer of reasoning cementing our ability to both defend and criticize aspects of current human rights practice'. ${ }^{51}$ The tandem conception allows bridging the sphere of moral ideas about intrinsic human interests, needs and capabilities with one of instrumental, political reasoning. Favouring the idea of global public reasoning, he sees the global public debate about the shared humanist grounds for assessing domestic and international institutional structures as crucial to preserving human rights as significant normative guidelines.

\section{Two extensions: recognition as guideline and cosmopolitan rights as a new category}

Following Gilabert's direction of thought in general, my proposal differs from his position mainly in two ways. First, I extend and concretise Gilabert's social understanding of human beings by using the recognition theoretical rights understanding of Axel Honneth. Second, I 
introduce the distinction between human rights and cosmopolitan rights to account for the important political international function of human rights that cannot be fully accounted for if defining them as individual rights in the first instance.

\section{Approaching the human subject of human rights in a recognition theoretical perspective}

To begin by elaborating the first extension, I identify with Gilbert's commitment to a more complex understanding of the human being as the subject of human rights that is not restricted to rational capacities and material needs but puts an additional strong focus on social and psychological vulnerabilities and needs. Based on Honneth's recognition theory, ${ }^{52}$ I defend a more concrete claim than Gilabert saying that the ascription of (human) rights can be crucial for the maintenance of individual self-esteem, especially if an individual suffers under repression from his or her own membership community. For example, focussing on those human beings that are especially in need of human rights guarantees such as poor families, migrants or disabled persons should not be equal to confronting their (costly) needs and claims but to the question of how their potential as social human rights agents can be activated and appreciated. The recent dominance of the political human rights understanding leads to a change in perspective particularly towards those human beings that are dependent on support, as they are not primarily approached and empathised with as beings with potential and dignity but as variables in a bigger political equation. In my understanding of Gilabert's intention to revalue humanist foundations in human rights theory, such a focus contributes to strengthening the international political value of the declaration. The theory of recognition can serve as an appropriate model to re-focus on human rights in a humanist, normative agency-centred way that accounts for the social, intersubjective relevance of human rights (as an idea and as a practice). As such, they can be a fundamental component of contemporary self-understanding, and serve as a normative guideline for the singular actors to identify with. A human rights idea that is graspable and self-esteem stabilising for anyone symbolises the ascription of dignity and moral responsibility both as a member of local, national communities and of the global society. ${ }^{53}$ Only with such a substantial and agent-centred (therefore de-politicised or pre-political) commitment, can a human rights theory be used as a legitimate normative guideline at the international political level.

What should a revised human rights conception account for to allow a worldwide bottom-up shared identification? It somehow has to account for the limits of human understanding, as Griffin stated. From a standpoint of recognition theory, the idea of basic material and physical needs must be extended by the emphasis on basic social needs that need to be fulfilled for a healthy psyche and the individual's individuation. Let me therefore take a brief excursion to the relevant concepts from recognition theory.

Distinguishing between three levels of recognition shaping human life and socialisation (love, rights, solidarity ${ }^{54}$ ), Honneth not only includes different levels of analysis of social relations but also provides a useful portfolio to think about a contemporary self-understanding of the social human being. The first mode of recognition is internalised through the emotional support a child gets in its early relationships with caregivers. Receiving basic support and love in the, by nature asymmetrical, relationship with its caregivers, the child experiences the fulfilment of its needs, acceptance despite a dependent state, and fundamental support in affect regulation. This (ideal) basis in primary relationships helps to develop a practical relation-to-self that is stabilised through basic self-confidence. The correlating forms of disrespect are abuse and rape, where physical integrity is the threatened 
component of personality. The second mode of recognition is experienced through the reenactment and understanding of cognitive respect as it is experienced in legal relations. Out of the cognitive understanding of the mutual relatedness and equality in legal relations, the personality experiences the ascription of moral responsibility and learns to de-formalise and generalise relationships to the Other. In the ideal process, the individual develops selfrespect as the practical relation-to-the-self. Correlating forms of disrespect are identified as the denial of rights and exclusion. These forms of disrespect threaten the social integrity of the personality. The third mode of recognition is experienced through social esteem in a community where the subject develops and becomes recognised for his traits and abilities. In the ideal developmental process, the individual internalises the deep understanding of solidarity as a form of recognition that unifies the community. Also, on this ground, the personality starts to differentiate, individualise and equalise in an ongoing personal individuation. The practical relation-to-self is developed as self-esteem. The correlating forms of disrespect are denigration and insult, threatening honour and dignity. ${ }^{55}$

All the levels of recognition are relevant for a comprehensive understanding of human rights, but it is specifically the second level of recognition, the juridical recognition, which is relevant for the human rights discourse. However, as the basis of social esteem and solidarity, it is closely interwoven with the third level. The guarantee of individual rights through a legitimate (national) authority but also via the practice of mutual ascription and respect of rights within the community one is living in provides the secure basis and internal psychic understanding allowing a human being to rely on and trust in social relationships, to collaborate and to find solidarity with others even if they are not able to provide any compensation for received support. The rights endowment of an individual within a community gives the subject the feeling of dignity and inclusion. This experience of recognition corresponds with a modus of practical self-relationship: The individual can be sure of the social value of his identity and is affirmed in his self-esteem. Even if 'rights' represent only a partial and general basis for the individual development of self-esteem, recognition as a legal person transports the basic understanding of oneself and the other as a carrier of legitimate individual entitlements.

At the individual level, the experience of being recognized as a legal person by the members of one's community ensures that one can develop a positive attitude towards oneself. For in realizing that they are obliged to respect one's rights, they ascribe to one the quality of morally responsible agency. However, because one necessarily shares the capacities thus entailed with all of one's fellow citizens, one cannot yet, as a legal person, relate positively to those of one's characteristics that precisely distinguish one from one's partners in interaction. For that, a form of mutual recognition is needed in which each individual is affirmed not only as a member of his or her community but just as much as a biographically individuated subject. ${ }^{56}$

According to the interlaced logic of recognition, the ascription of rights and the practice of social esteem are necessary for the development of internalised solidarity but also crucial for the individual's psychological individuation. If the moral human right reasoning becomes adjusted to questions of recognition, the genuine bridge between the private (social, relational aspects), the political (rights, communal commitment) and the international sphere (solidarity for strangers) that human rights should cover becomes more explicit and conscious again.

Besides this short overview of how a humanist, social understanding of the human rights agent in Gilabert's sense could be considered, my account differs from Gilabert's also by putting more weight on anthropological thoughts but less emphasis on the belief in global public consent. I suggest that revealing and strengthening the unifying potential 
of a humanist human rights idea requires raised awareness for its ideal theoretical value. The positive imagination of a better life for every human being transported through the human rights idea and realised through a shared understanding of the project has a symbolic, and therefore a normative, motivational function. Introduced in a comprehensive way, the shared narrative allows a rational, intellectual, but also an affective identification and commitment of individuals worldwide. Following Gilabert's distinction between abstract and specific human rights and using it as a substitution for the conceptual distinction between moral and political human rights, I emphasise the potential of abstract rights with regard to individual identification and their motivation to actively advocate the human rights idea. Abstract human rights can provide a vivid ideal imagination of a better life for anyone. To concentrate on how such a contemporary human self-understanding could be elaborated, I argue more explicitly in favour of an independent, accessible moral human standpoint serving as a point of reference for any philosophical human rights derivations as well as for political implementations. I would like to point out the necessity of an institutionalised philosophical human rights roundtable that hosts and contains the diversity of philosophical human rights conceptions. The function of such an institution would be to provide a substantial, transparent value discussion in periodic meetings. Such an institution, maybe as a part of the United Nations Human Rights Council (UNHRC), could provide explicit discussion about our contingent self-understanding as human beings as grounds for further reflections about human rights practicalities. Such a philosophical 'think tank' reasoning would involve both an intrinsic moral ground and practical-oriented political dimension. The idea would be that an ongoing and targeted discussion about the social and political self-understanding and moral attitude would determine what is intrinsically valuable and legitimate. This keeps the level of normative awareness high and the reflection process in operation. This reflection-zone can work as a normative corrective, as a field in which the justification of abstract human rights and cosmopolitan rights can be approached on neutral ground, first of all free from power-political preliminaries. It is not the point of this article to elaborate the idea of such a roundtable in further detail, but it is one that deserves further attention. Whereas the realisation of global public consent seems very ambitious and hard to pin down, a concentrated diversity-hosting human rights roundtable seems to have better chances to find common understandings and goals. The periodic meeting could assure a constant self-obligation to revise and reflect about the current standards. The non-dogmatic but institutionalised, central and transparent circle could serve as a point of orientation in demanding normative justification for international action if executed in the name of human rights.

\section{Human rights and cosmopolitan rights: from individual, social through to global level}

The second extension in comparison to Gilabert is my argument that an individual rights understanding, as outlined, needs to be completed by a global, international dimension of human rights. As I will argue in the following section, the mere understanding of human rights as individual rights cannot fully account for all those (human well-being related) issues caused by international political interdependences that have been related to the concept of human rights in the contemporary global context. Whereas human rights provide grounds for immediate and needs-related claims against one's own social community or national government, cosmopolitan rights represent those interests that arise from a global comparative view against the background of a highly politically and economically interdependent world. They allow acknowledging political interests and needs of individuals and groups that are, for example, clearly disadvantaged through 
either power-political or economic global interdependences. Whereas the term human rights refers to the shared membership in humankind, the term cosmopolitan rights refers to the shared membership in the international or transnational political and economic community. I therefore suggest introducing an additional distinction between human rights and cosmopolitan rights, both having an abstract and a specific dimension.

This article has argued so far that any human rights conception must be explicitly premised on a minimal moral, substantive core of human rights. Human rights as moral claims have to be determined with respect to the intrinsic value of social human beings. The transmission from abstract (moral) to specific (legal, practical) human rights has to be discussed with respect to practicalities. Turning to the political function of human rights it is now time to address the question of how such a 'social' moral conception of human rights could serve as a point of orientation to include the global political dimension of human rights. The distinction between intrinsic and instrumental must therefore be calibrated in reference not only to the two poles of 'abstract moral values' and 'specific practicalities', but it also has to accommodate the inter-state and global political dimension. To demarcate an individual and intersubjective human rights dimension from a global, political one, it is proposed to distinguish between (a) abstract human rights and specific human rights, and (b) abstract cosmopolitan rights and specific cosmopolitan rights. 'Human rights' are distinctly defined as rights of 'the human being'; moral and political 'cosmopolitan rights' are established as specified human rights guiding a content-related kind of human governance and responsive to a changed geopolitical world order.

The core dimension of moral or abstract human rights remains at the individual level. At the individual level, abstract (moral) human rights are distinguished from specific (practical) human rights. At the inter-state and global political levels abstract (moral) cosmopolitan rights are distinguished from specific (practical) cosmopolitan rights. The transmission of abstract human rights to specific human rights as well as the determination from abstract and specific cosmopolitan rights takes place under the normative 'magnifying glass' of the moral human standpoint at the outlined philosophical roundtable. Evaluating international politics then means orienting global aims, standards and actions against the question of human well-being and future cross-generational implications. Principles of state sovereignty, collective self-determination and social justice would be considered as inherently bound to a moral conception of human rights so that they could legitimately assume a public and standard-setting role in international politics. The social dimension of human rights has to be valued also at the cosmopolitan dimension. For this purpose, the respective scope of human rights and of cosmopolitan rights has to be distinguished.

First, defining 'specific human rights' as tied to 'abstract human rights' means adjusting them to the individual, intersubjective local dimension that affects life conditions before linking further claims to the cosmopolitan aims of international, global politics. The intersubjective, social dimension of human rights is necessarily interwoven with the local political dimension, since political participation, welfare, goods and services, tax liability, etc., are still predominantly managed at national level. Taking the social affectedness and recognition processes as crucial for the moral conception of human rights and its subjective reenactment, derived practical human rights should incorporate claims towards the other, within a social or cultural community, and towards their own government. National governments are the dedicated first instance to guarantee human rights within state territory. Confining the formal 'territory' of human rights to the realm of national politics is then artificially but reasonably upheld to distinguish human rights from 'cosmopolitan rights', as rights that can be claimed at the responsible, international level. 
Second, whereas cosmopolitan rights incorporate the normative core of human rights, in their practical form they also allow a further specification that adjustably corresponds with the de facto changed world order, shaped by various economic, political and cultural interdependences, a gradual degradation of states and states-systems against the background of the increasing importance of global governance. As 'world-political' human rights, cosmopolitan rights would have to be specified and extended in terms of membership in a cosmopolitan political community. Contrary to human rights that help to claim rights towards the other within a local community or (more traditionally) against and from one's own national government, cosmopolitan rights have to account for those cases when national human rights protection fails, but also for cases that require global governance solutions because they transcend mere national interests (climate change, genetic engineering, humanitarian interventions, etc.). Whereas cosmopolitan rights share the same normative core with human rights, they have an extended scope covering transnational and global issues. Following the assumption of a 'law of proximity', the conduct of both individuals and governments is foremost framed by envisaged spatial, temporal, social or modal consequences in one's own near environment and concerning one's own affectedness. ${ }^{57}$ Increased distances that possibly diminish personal solidarity of course complicate the implementation of cosmopolitan rights. This factor is highlighted exemplarily when humanitarian interventions are blocked by national parliamentary decisions, for instance, for fear of losing too many lives of soldiers and too many resources - which might be comprehensible from a personal perspective but is out of proportion if one considers the harm done to the affected people. Distinguishing between human rights and cosmopolitan rights allows analysing and responding to such divergences by using a more specified terminology.

Further research might investigate the proposed fourfold distinction between human rights. Research questions would have to be specified with regard to the following particular fields: abstract human rights, specific human rights, abstract cosmopolitan rights and specific cosmopolitan rights. For instance, questions about human self-understanding, existential and social needs, capabilities, and human values are associated with the 'abstract human rights field'. Based on such a 'moral human standpoint', it is asked how these challenges could theoretically be met within societies and by governmental institutions. The 'specific human rights field' is hosting questions such as 'How can theoretical assumptions become applied and implemented in the context of the given? What institutions and legal rights can optimally provide for the implementation of moral human rights in the "real world"'? The reasoning within the 'abstract cosmopolitan rights field' is concerned with the question of how human rights have to be extended or adapted in relation to structuring concepts of cosmopolitanism, (global) governance, (social) justice, division of responsibilities between states and transnational institutions, etc. Thus, cosmopolitan rights as rights concerned with moral claims might for example (compared to abstract human rights) not focus on immediate levels of suffering of particular human beings (like actual incidents of torture) but instead articulate claims from the perspective of collective or crossgenerational danger that need to be mitigated by long-term transnational solutions (for example, globally guaranteed prevention measures against natural or climate change disasters). The coherence between abstract cosmopolitan rights and abstract human rights has to be carefully examined. Questions about the implementation of abstract cosmopolitan rights would be hosted within the 'specific cosmopolitan rights field' discussion, which would again discuss the question of optimal realisation within a given social and geopolitical context. 


\section{Towards a humane governance}

A current approach in political theory that resonates with the outlined human rights understanding is spelt out in Richard Falk's 'On Humane Governance'. ${ }^{58}$ Criticising the geopolitical strategies of globalisation as directed by 'wealth and power' as 'the norms of value', Falk designs a normative geopolitical account that bases its legitimation on the recognition of 'sane and intelligent persons' ${ }^{59}$ According to Falk, to direct the structures and practices of governance methodically into humane directions in order to diminish the gap between it and geopolitical and economic processes, democratic means are required. What could well be called a cosmopolitan citizen standpoint must therefore encompass more than normatively neutral criteria like the geopolitical functionality of coordinating mechanisms and economic efficiency at regional and global levels. This kind of (moral) 'personalisation of geopolitics' is understood as the claim to include the kind of personal evaluation that is generally expected from 'sane and intelligent' individuals. The idea is simply to base inter-state and global decisions systematically on the normative benchmark of human needs and values. Individuals represent the smallest entities within the global political space and should therefore, according to Falk, be awarded with a larger influence.

\footnotetext{
Most conceptions of geogovernance are limited to coordinating mechanisms at regional and global levels. This view of humane governance is one that links the global and regional to the national and personal. The aggregation of the various sites of governance from the local and personal to the global and bureaucratic cumulatively constitute humane governance. The inclusion of the personal within the scope of humane governance is an acknowledgement of, for example, feminist claims that the home and family are units of social control that model behavioural roles in public space. The work of women has been habitually neglected by locating its domain within the sphere of 'the personal', which is excluded from assessments of governance. $^{60}$
}

For sure, linking 'the global and regional to the national and personal' requires having a distinct pool of concepts and values ascribed to the human being in question. For this purpose, the outlined conception of human rights, understanding human rights as a concept that is defined with respect to the personal, intersubjective dimension, may provide a fertile ground. Such a concept of human rights would get its political meaning in terms of offering a benchmark for domestic and international politics. Combining the concept of human rights with a concept of humane governance, the dimension of abstract moral values could provide a pool for claiming abstract rights that protect substantial human capabilities while taking into account the humane vulnerability in various social contexts. A moral conception of human rights should be valued as a necessary theoretical viewpoint for the evaluation of geopolitics.

Implementing human rights against the background of international politics and asymmetries would require specifying them as rights that human beings and associations possess to be protected in the first instance by and from their governments, and in the second instance guaranteed due to their belonging to the cosmopolitan community. This distinction of two scopes is not meant to dissolve the divided responsibilities of states and the international community. It rather untangles the enmeshment in theory and practice towards a reasonably clear and realistic conception of human and cosmopolitan rights. The proposal of a two-dimensional account is similar to Beitz's 'two level-model' rights primarily as requirements whose object it is 'to protect urgent individual interests against certain predictable dangers ("standard threats") to which they are vulnerable under typical circumstances of life in a modern world order composed of states'. According to Beitz, human rights apply in the first instance ('first level') to the political institutions of 
states, including their constitutions, laws and public policies. At a second level, human rights are matters of international concern. In case of a government's failure to carry out its first-level responsibility, the second-level agents outside the state have to take action. ${ }^{62}$ Beitz's two-level model offers an attractive example for how to structure the practical dimension of human rights. ${ }^{63}$ In light of Beitz's recent gesture towards moral conceptions by considering the value of human dignity, such a model could reasonably be proven compatible with the draft of a moral conception of human rights. ${ }^{64}$

\section{Conclusion}

This study proposed to overcome the established - but inherently vague - distinction between moral and political conceptions of human rights in philosophical debate. Therefore, Gilabert's distinction between abstract and specific human rights was adopted to bridge both readings in a complementary way. The substantial conception of human rights advocated in this article seeks to reshape the debate to a more clear and practicable concept of human rights that is debated on moral grounds, practically operative, but averting the risk of being determined by power political decision-making or political instrumental interpretation. It is clearing a space for approaching the question of humanity within human rights discourse without being restricted by strategic political considerations from the very beginning. It is such a (at least to a minimal degree) freestanding - and contingent - moral conception of human rights that allows the expression of political claims and the criticism of domestic and international politics by reference to moral values and the requirements of social life as earlier outlined under the recognition theoretical perspective. While assuming an intrinsic value shared by human and cosmopolitan rights, the proposed model emphasises especially the distinction between requirements of a moral human standpoint, from where abstract human rights are derived and must be transmitted into specific human rights, and an extended cosmopolitan standpoint, from where abstract cosmopolitan rights are derived and have to become transmitted into specific cosmopolitan rights.

Having argued for the necessity of a moral conception of human rights if and only if understood by means of relational, social criteria, it has to be asked why this model provides a better foundation than the classical moral conception of absolute values when it comes to derive human rights. How are these human rights distinguished from merely traditional individual rights? To what degree does the new conception allow for a better response to the criticisms against classical moral conceptions? The included social dimension that complements the understanding of intrinsic values might serve as a foundation to mark them out as rights that genuinely carry the investment of a social and, by implication, a political dimension. As Joshua Cohen writes, human rights are rights that always frame the membership-conditions of the individual within a community. ${ }^{65}$ The intersubjective, social dimension that is already included in the basic normative definition of human rights in the outlined conception is a distinct feature mostly put in second place in liberal individual (atomistic) conceptions of human rights. This feature incorporates a contingent social dimension of human life into the conceptualisation of human rights that serves to mitigate the objection against moral foundationalism.

Not to put too fine a point on it, questions about the self-understanding of the human being, about what implications this self-understanding should carry for personal, social, national and cosmopolitan orientation and claims cannot be answered on the basis of an ultimate anthropology. As Emil Angehrn writes, the definition of the human being must not be one that we find in nature or in the order of things, but one that the human being gives to itself. ${ }^{66}$ An anthropological anchoring of human rights with a transcultural validity 
claim can therefore only be articulated as the shared human potential to create and reflect about ends and values. The aspiration of political conceptions of human rights to decide and deliberate about human rights is thus no longer bound to the standpoint of powerful global actors, but to the normative standpoint of a human being as a 'self-interpreting animal', ${ }^{67}$ able to reflect and to shape its relation to self and other in a social and political environment. By this theoretical shift of the prerogative of interpretation, an obligation is gained to monitor cosmopolitan rights decisions through a 'magnifying glass' of this very human standpoint.

\section{Disclosure statement}

No potential conflict of interest was reported by the authors.

\section{Notes on contributor}

Anita Sophia Horn is a PhD candidate in political philosophy at the University of Zurich (scholarship from the Swiss National Science Foundation). Further, she works as a political science research assistant in international relations at the Law School of the University of St. Gallen.

\section{Notes}

1. Manfred Nowak, Karolina M. Januszewski, and Tina Hofstaetter, eds, All Human Rights for All. Vienna Manual on Human Rights (Vienna: Neuer wissenschaftlicher Verlag, 2012).

2. Andrew Fanagan, 'Human Rights', Internet Encyclopedia of Philosophy (IFP), http://www.iep. utm.edu/hum-rts/ (accessed 17 September 2013).

3. James Griffin, 'Human Rights: Questions of Aim and Approach', in The Philosophy of Human Rights. Contemporary Controversies, ed. Gerhard Ernst and Jan-Christoph Heilinger (Berlin; Boston, MA: De Gruyter, 2012), 3.

4. Ibid., 6 .

5. Fabienne Peter, 'The Human Right to Political Participation', Journal of Ethics and Social Philosophy 7, no. 2 (2013): 2.

6. Ibid., $2 \mathrm{f}$.

7. Charles R. Beitz, The Idea of Human Rights (New York: Oxford University Press, 2009), xii.

8. Ibid.

9. Ibid., $102 \mathrm{f}$.

10. Cf. also Alan Gewirth, Human Rights. Essays on Justification and Applications (Chicago; London: The University of Chicago Press, 1982), xi.

11. For two historical overviews compare for example, Carl Wellman, The Moral Dimensions of Human Rights (Oxford: Oxford University Press, 2011), Ch. 1, and Morton E. Winston, The Philosophy of Human Rights (Belmont, CA: Wadsworth, 1989), 1-42.

12. Winston, The Philosophy of Human Rights, 3.

13. David Boersema, Philosophy of Human Rights: Theory and Practice (Boulder, CO: Westview Press, 2011), 47.

14. Gewirth, Human Rights, ix.

15. Arnd Pollmann and Georg Lohmann, eds, Menschenrechte. Ein interdisziplinäres Handbuch (Stuttgart; Weimar: Metzler, 2012), 331-7.

16. Charles R. Beitz, 'Human Rights as a Common Concern', The American Political Science Review 9, no. 2 (2001): 273.

17. Pollmann and Lohmann, Menschenrechte, 333.

18. Isaiah Berlin and Henry Hardy, Against the Current: Essays in the History of Ideas (Princeton, NJ: Princeton University Press, 2001), 22.

19. Jack Donnelly, 'The Social Construction of International Human Rights', in Human Rights in Global Politics, ed. Tim Dunne and Nicholas J. Wheeler (Cambridge: Cambridge University Press, 1999), 71. 
20. Christoph Menke and Arnd Pollmann, Philosophie der Menschenrechte (Hamburg: Junius, 2007), 9-22. Compare also: ibid.

21. Menke and Pollmann, Philosophie der Menschenrechte. Historians such as Samuel Moyn and Mark Mazower objected to this prevalent historic view. They argue that the absence of a joint letter of intent in addition to the UDHR of 1948 suggests that the founders never meant to institutionalise human rights as legal safeguards against genocide. If so, an international mandatory letter of intent allowing the overriding of individual state sovereignty in case of their infringement of international law ought indeed to have been institutionalised. Axel Honneth, 'Paradoxien der Menschenrechte. Bemerkungen zu neueren historischen Untersuchungen', in Menschenrechte und Demokratie (Freiburg; München: Karl Alber, 2013), 257; Samuel Moyn, The Last Utopia. Human Rights in History (Cambridge, MA, London: Harvard University Press, 2010); Mark Mazower, Governing the World. The History of an Idea (London: Allen Lane, 2012). Be this as it may, an explicit reference to 'barbarous acts' is made in the preamble of the UDHR, thus both interpretations seem acceptable. Cf. Universal Declaration of Human Rights (New York: United Nations Department of Public Information), http://www.ohchr.org/ en/udhr/pages/Language.aspx?LangID=enghttp://www.ohchr.org/en/udhr/pages/Language.

aspx?LangID=eng (accessed 8 July 2013).

22. Beitz, The Idea of Human Rights, 105.

23. Ibid., 106.

24. Ibid., 105f.

25. Pablo Gilabert, 'Humanist and Political Perspectives on Human Rights', Political Theory 39, no. 4 (2011): 440.

26. Beitz, The Idea of Human Rights, 103.

27. Peter, 'The Human Right to Political Participation', 4.

28. Joseph Raz, 'Human Rights in the New World Order', in Columbia Public Law \& Legal Theory Working Papers (NELLCo Legal Scholarship Repository, Columbia Law School, 2009), 15.

29. Ibid.

30. Yet, the confession of such allegedly universal ethical values as human dignity, equality and freedom constitutes a fundamental part of the UDHR. The preamble states: 'Whereas recognition of the inherent dignity and of the equal and inalienable rights of all members of the human family is the foundation of freedom, justice and peace in the world, [... . Now, therefore, the General Assembly, proclaims this Universal Declaration of Human Rights as a common standard of achievement for all peoples and all nations [... ].' Universal Declaration of Human Rights (New York: United Nations Department of Public Information), http://www. ohchr.org/en/udhr/pages/Language.aspx?LangID=eng (accessed 8 July 2013). UDHR documents are full of such moral vocabulary ('inherent dignity', 'equal and inalienable right', 'members of a human family').

31. Beitz, 'Human Rights as a Common Concern'.

32. John Rawls, The Law of Peoples, 4th ed. (Cambridge, MA; London: Harvard University Press, 2002)

33. Charles R. Beitz, 'Human Dignity in the Theory of Human Rights: Nothing But a Phrase?', Philosophy and Public Affairs 41, no. 3 (2013): 260.

34. Peter, 'The Human Right to Political Participation'.

35. These values are named and used as core values of the European Union. European Union, 'Human Rights and Equality', How the European Union Works, http://europa.eu/about-eu/ index_en.htm (accessed 14 September 2013).

36. 'Political theorists have been good at unravelling the complex ancestry of ideas about rights, and dissecting such conceptual questions as whether there are such things as universal values, or how to measure social against civil rights. Once again, however, the ideas are disembodied and plucked from historical context.' Mark Mazower, 'The Strange Triumph of Human Rights', The Historical Journal 47, no. 2 (2004): 380, http://www3.nccu.edu.tw/ lorenzo/ Mazower\%20Strange\%20Triumph\%20of\%20Human\%20Rights.pdf (accessed 14 September 2014).

37. Fanagan, 'Human Rights' http://www.iep.utm.edu/hum-rts/.

38. Andreas Thier identifies this tension between international possibilities and supranational aspirations in international law as one between 'positivity' and 'extra positivity'. Andreas Thier, 'Der Begriff des Völkerrechts' (Tagung 'Völkerrechtsphilosophie der Frühaufklärung', Kappel am Albis (Switzerland), 2013), 2. 
39. The talk between Mads Andenas from the University of Oslo and Thomas Gammeltoft-Hansen from the Danish Human Rights Institute took place in the panel 'Human Rights in Times of Economic Crisis', at the Association of Human Rights Institutes 2013 Annual Conference on 'Emerging Research in Human Rights', 9-11 September 2013, University of London.

40. 'However, the term "human rights" covers an extremely wide range of subjects from fundamental liberties to matters which fall under the category of "rights" only by ingenious legal pleading. The courts must not become so political that they consistently undermine the will of the people as expressed through a popularly elected and sovereign legislature on a wide range of matters with little relevance to basic human rights. It is dangerous for democracy to permit judges to become politicians in robes and to substitute their moral judgements for those of elected representatives on issues outside their essential but circumscribed field. When they are under attack, as they unfortunately have been during the past decade in the UK, human rights and accepted legal procedures need to be safeguarded by the courts.' Michael Pinto-Duschinsky, 'Bringing Rights Back Home. Making Human Rights Compatible with Parliamentary Democracy in the UK' (Policy Exchange), 5, http://www.policyexchange.org.uk/publications/category/item/ bringing-rights-back-home-making-human-rights-compatible-with-parliamentary-democracyin-the-uk (accessed 14 September 2013).

41. Following Michael Walzer, it is exactly this tension that has to accompany the critical enterprise as a common mark: 'It (the critical enterprise) is founded in hope; it cannot be carried on without some sense of historical possibility. Criticism is oriented toward the future: the critic must believe that the conduct of his fellows can conform more closely to a moral standard than it now does or that their self-understanding can be greater than it now is or that their institutions can be more justly organized than they now are.' Michael Walzer, The Company of Critics. Social Criticism and Political Commitment in the Twentieth Century (New York: Basic Books, 1988), 17.

42. John Tasioulas, 'Human Rights, Legitimacy, and International Law', The American Journal of Jurisprudence 58, no. 1 (2013): 2, doi:10.1093/ajj/aut001.

43. Gilabert, 'Humanist and Political Perspectives on Human Rights', 444.

44. Ibid., 449-50.

45. Ibid., 443 .

46. Ibid.

47. Ibid., 441.

48. Ibid.

49. Ibid., 444.

50. Ibid.

51. Ibid., 441.

52. Axel Honneth, Kampf um Anerkennung - Zur moralischen Grammatik sozialer Konflikte (Frankfurt am Main: Suhrkamp, 1994).

53. Ibid.

54. Ibid., 176f.

55. Axel Honneth, The Struggle for Recognition: The Moral Grammar of Social Conflicts, trans. Joel Anderson (Cambridge: Polity Press, 1996), 129.

56. Ibid., 80 .

57. Manfred Walther, 'Ein analytischer Blick auf die Fragilität zwischenstaatlicher Beziehungen. Spinozas Beitrag zu den Bedingungen eines internationalen Rechts im politischen Traktat, Kapitel III' (Tagung 'Völkerrechtsphilosophie der Frühaufklärung', Kappel am Albis (Switzerland), 2013), 4.

58. Richard Falk, On Humane Governance. Toward a New Global Politics (University Park: Pennsylvania State University Press, 1995).

59. 'This book is written on the assumption that sane and intelligent persons should be giving affirmative answers to these questions. Only with such confidence can there be any genuine hope for the sort of transformative adjustments that are needed if we as a species, and as a network of distinct cultures, races, and religions, are to make this earth a benevolent habitat in the decades ahead.' Ibid., 17.

60. Ibid.

61. Beitz, The Idea of Human Rights, 106-17.

62. Ibid., 109. 
63. The proposed distinction between the level of human rights on the one hand, and the level of cosmopolitan rights on the other hand can be further aligned along levels of analysis such as those elaborated by Joshua S. Goldstein or John Rawls. Rawls' idea of a basic structure of well-ordered society that entails the three levels of justice (local, domestic and global) shows how an abstract idea ('justice as fairness') is matched by appropriate units. John Rawls, Justice as Fairness: A Restatement (Cambridge, MA: Harvard University Press, 2001), 11. Distinguishing even more subtly between individual, domestic, inter-state and global levels, Goldstein adds specific conflicts and relevant actors at each level. The individual level of analysis concerns the perceptions, choices and actions of individual human beings. The domestic level of analysis concerns the aggregations of individuals within states that also influence state actions in the international arena. The inter-state level of analysis concerns the influence of the international system upon outcome. The global level of analysis seeks to explain transnational outcomes in terms of global trends and forces that transcend the interactions of states themselves. This last level of analysis is said to deserve particular attention because of the growing importance of global-level processes. Joshua S. Goldstein, International Relations, 6th ed. (New York: Pearson Longman, 2011).

64. 'One conclusion that emerges from our reflections so far is that any conception of human dignity of normative interest will have to include a "value" element. Without some moral content, conceptions framed in terms of status or respectfulness will be too thin to do useful work in a theory of human rights. Another is that ideas of human dignity seem to apply (differently) at two distinct levels of thought about human rights - as a feature of a public system of norms and as a more specific value that explains why certain ways of treating people are (almost?) always impermissible.' Beitz, 'Human Dignity in the Theory of Human Rights', 283.

65. Joshua Cohen, 'Minimalism About Human Rights: The Most We Can Hope For?', The Journal of Political Philosophy 12, no. 2 (2004): 190-213.

66. Emil Angehrn, 'Menschenrechte und Menschenbilder. Eine anthropologisch-hermeneutische Reflexion', in Menschenrechte und Demokratie (Freiburg; München: Karl Alber, 2013), 29.

67. Charles Taylor, Human Agency and Language (New York: Cambridge University Press, 1985), $45-76$. 